\title{
Dose-response effect of crude extracts produced by actinobacteria on in vitro rumen fermentation
}

\author{
Padrão dose-resposta de extratos brutos produzidos por actinobactérias sobre a fermentação \\ ruminal in vitro
}

\author{
Bruna Gomes ALVES ${ }^{1}$; Cristian Marlon de Magalhães Rodrigues MARTINS' ${ }^{\mathbf{1}}$; Marcos André ARCARI'; \\ Ana Paula Ferranti PETI²; Luiz Alberto Beraldo de MORAES²; Marcos Veiga dos SANTOS ${ }^{1}$ \\ ${ }^{1}$ Universidade de São Paulo, Faculdade de Medicina Veterinária e Zootecnia, Departamento de Nutrição e Produção Animal, \\ Pirassununga - SP, Brazil \\ ${ }^{2}$ Universidade de São Paulo, Faculdade de Filosofia, Ciências e Letras, Departamento de Química, Ribeirão Preto - SP, Brazil
}

\begin{abstract}
Actinobacteria have been researched as a source that produces crude extracts, which contain bioactive compounds able to act as antimicrobial agents. The present investigation evaluated the dose-response effect of two crude extracts, obtained at Caatinga rhizosphere (Caat) and Rhizophora mangle (AMC), on in vitro ruminal fermentation by: cumulative gas production, digestibility of dry (IVDMD) and organic matter (IVOMD), and short-chain fatty acids concentration (SCFA). Three multiparous Holstein dairy cows with ruminal fistula were used as the inoculum donors and fed a basal diet consisting of corn silage, soybean meal, urea, ground corn and mineral supplement. Ruminal fluid samples were incubated in glass bottles with $1 \mathrm{~g}$ of the dried and milled diet, a buffer solution, and the crude extracts evaluated in four doses $(0.3,0.6,0.9$ and $1.20 \mathrm{mg} / 10 \mathrm{~mL}$ inoculum) in a randomized block design, and the donators were considered as blocks with random effects. Additionally, negative controls were used. The results were expressed as average values based on triplicate analyses. Decreased cumulative gas production was observed according to linear dose response at 24,48 and $72 \mathrm{~h}$ of incubation with the addition of Caat extract. The IVOMD showed a linear decrease at $72 \mathrm{~h}$ of incubation with dose Caat inclusion. Furthermore, the inclusion of Caat extract linearly reduced butyric and isovaleric acid concentrations, as well as acetate:propionate ratio. Finally, the Caat inclusion increased the propionic acid concentration in comparison to AMC extract. However, the inclusion of AMC extract did not affect any of the analyzed variables at the used doses. The Caat extract could be used as a modulator of in vitro ruminal fermentation, since it reduced acetate:propionate ratio and cumulative gas production.
\end{abstract}

Keywords: Actinobacteria. Ionophores. In vitro fermentation. Extracts.

\section{Resumo}

As actinobactérias têm sido pesquisadas como fonte produtoras de extratos brutos que contêm compostos bioativos capazes de atuar como agentes antimicrobianos. O presente trabalho investigou o efeito dose-resposta de dois extratos brutos, AMC e Caat, na fermentação ruminal in vitro por: produção cumulativa de gás, digestibilidade in vitro da matéria seca (IVDMD) e matéria orgânica (IVOMD) e concentração de ácidos graxos de cadeia curta (SCFA). Três vacas leiteiras da raça Holandesa, multíparas e portadoras de fístula ruminal foram utilizadas como doadoras de inóculo ruminal e foram alimentadas com uma dieta basal composta por silagem de milho, farelo de soja, ureia, milho moído e suplemento mineral. As amostras de inóculo ruminal foram incubadas em garrafas de vidro com $1 \mathrm{~g}$ da dieta seca e moída, solução tampão e os extratos brutos avaliados em quatro doses $(0,3,0,6,0,9$ e $1,20 \mathrm{mg} / 10 \mathrm{~mL}$ de inóculo) em delineamento em blocos casualizados, sendo as doadoras consideradas os blocos como efeito aleatório. Além disso, foram utilizados controles negativos para a correção da produção de gás. Os resultados foram expressos como valores médios com base em análises triplicadas. A diminuição da produção cumulativa de gás foi observada de acordo com a dose em resposta linear às 24,48 e $72 \mathrm{~h}$ de incubação com a adição de extrato de Caat. A IVOMD mostrou uma diminuição linear com $72 \mathrm{~h}$ de incubação com inclusão de Caat. Além disso, a inclusão do Caat reduziu linearmente as concentrações de ácido butírico e isovalérico, bem como a proporção de acetato/propionato. Diferentemente, a inclusão do extrato de AMC não afetou nenhuma das variáveis analisadas nas doses utilizadas. O extrato de Caat pode ser usado como um modulador da fermentação ruminal in vitro, uma vez que reduziu a proporção de acetato/propionato e a produção de gás acumulada.

Palavras-chave: Actinobactérias. Ionóforos. Fermentação in vitro. Extratos. 
Correspondence to:

Marcos Veiga dos Santos

Universidade de São Paulo, Faculdade de Medicina Veterinária

e Zootecnia, Departamento de Nutrição e Produção Animal

Av. Duque de Caxias Norte, 225

CEP 13635-900, Pirassununga, SP, Brazil

e-mail: mveiga@usp.br

Received: 05/12/2017

Approved: 15/02/2018

\section{Introduction}

Ionophores have been used as additives in ruminant nutrition to modulate ruminal fermentation by inhibiting Gram-positive ruminal microorganisms (RUSSELL; STROBEL, 1989). Previous studies evaluated the inclusion of monensin, one of the most widespread ionophores used, and reported results on the reduction of methane (NARVAEZ et al., 2013), decrease of protein deamination (DINIUS et al., 1976; NARVAEZ et al., 2013), and an increased propionic acid concentration (MCGUFFEY et al., 2001) in the rumen. Although beneficial effects on ruminant production have been reported with the use of monensin sodium and its analogs, some studies have demonstrated the difficulty of visualizing significant effects when the animal goes through a long period submitted to ionophores (NEWBOLD et al., 1993) or when it is offered to animals not adapted to the compounds (DOMESCIK; MARTIN, 1999). This increased resistance of the organism to the compound can be attenuated by a greater variety of active compounds used, as well as with different sources of origin. In view of this, it is necessary to discover new alternatives that play a role as the ionophores in the modulation of ruminal fermentation, thus allowing a greater range in the availability of feed additives.

Natural metabolites produced by actinobacteria, fungi and cyanobacteria have been identified as a source of bioactive compounds that present antimicrobial activity (LAZZARINI et al., 2000). Recently, two crude extracts produced by actinobacteria were isolated from specific environments in Brazil; the first isolated from Caatinga rhizosphere (Caat) and the other isolated from the mangrove rhizosphere (Rhizophora mangle - AMC) (CREVELIN et al., 2014). These crude extracts can produce some secondary metabolites that are a large source of compounds that have biological activities. The main compounds present in these crude extracts are associated with the class of macrotetrolids (antibiotics isolated from actinobacteria, known as nonactin, monactin, dinactin, trinactin and tetranactin) and can act as antibiotics with ionophore function (transport of transmembrane cations) (CREVELIN et al., 2013).

Although previous studies evaluated other alternatives to the use of ionophores, such as yeasts, organic acids, plant extracts, probiotics, and natural products (CALSAMIGLIA et al., 2007), no studies have evaluated crude extracts produced by actinobacteria on in vitro rumen fermentation. In this study, we tested whether the inclusion of AMC and Caat crude extracts produced by actinobacteria would modulate ruminal fermentation, reducing the production of total gases and increasing propionic acid concentration, without altering the digestibility of dry matter and organic matter.

Therefore, the objective of this study was to evaluate the effects of four doses of two crude extracts (AMC and Caat) on in vitro rumen fermentation over a $72 \mathrm{~h}$ period, which was measured by total gases production, short-chain fatty acids (SCFA) concentration and in vitro dry matter and organic matter digestibility (IVDMD/IVOMD).

\section{Materials and Methods}

\section{Selection of crude extract of actinobacteria and chemical characterization}

The experimental protocol was approved by the Ethics Committee on Animal Use of the School of Veterinary Medicine and Animal Sciences, at the University of São Paulo ( ${ }^{\circ}$ 2038140514). The two crude extracts (AMC and Caat) used in this study were 
provided by the Laboratory of Mass Spectrometry Applied to Natural Products (LEMAPN) of the Department of Chemistry at the University of São Paulo. Actinobacteria were provided from Microorganisms of Agricultural and Environmental Importance Collection (CCMA, EMBRAPA, Brazil). The strains were maintained as suspensions of mycelia fragments in glycerol $(20 \%, \mathrm{v} / \mathrm{v})$ at $-20^{\circ} \mathrm{C}$, and cultured on glucose-yeast extract agar (GYEA) at room temperature.

Actinobacteria were cultivated in $125 \mathrm{~mL}$ Erlenmeyer flasks containing $25 \mathrm{~mL}$ PD (potatodextrose) medium at $30^{\circ} \mathrm{C}$ under shaking $(150 \mathrm{rpm})$ for 10 days. Crude extracts were obtained by simple liquid culture filtration followed by liquid-liquid extraction with ethyl-acetate. The organic phase was dried, and the crude extracts obtained were diluted with methanol at a final concentration of $1.0 \mathrm{mg} / \mathrm{mL}$, and the solution was stored at $4^{\circ} \mathrm{C}$.

A total of 74 out of 500 actinobacteria isolates produced crude extracts with activity similar to the macrotetrolides such as nonactin, monactin, dynactin, trinactin, valinomycin and actinomycin as described by Jani et al. (2008). From these crude extracts, we chose two extracts (AMC and Caat) that showed a higher number of active metabolites with ionophore activity, capable of transporting cations through membranes. The AMC extract showed similar activity to macrotetrolides and valinomycin, while Caat extract showed similar activity to actinomycin.

The crude extract AMC was characterized by Crevelin et al. (2013). This crude extract presents the production of macrotetrolids class and valinomycin as main compounds. The analysis of Caat crude extract using LC-MS showed exclusively the production of one main peak retention time at $5.3 \mathrm{~min}$ (Figure 1). This peak presents ion of $m / z 1225$ and 1277, which were attributed to ionic species $[\mathrm{M}+\mathrm{H}]^{+}$and $[\mathrm{M}+\mathrm{Na}]^{+}$, respectively. The collision-induced dissociation (CID) experiment for ion of $\mathrm{m} / \mathrm{z} 1225$ showed a fragmentation profile similar to actinomycin (WILLS; O'CONNOR, 2014). The ions of $m / z$ 399, 300 and 203 were attributed to the amino acid chain fragment ions of [(H-Val-Pro-Sar-MeVal-OH $)+\mathrm{H}]{ }^{+}$, [(H-Pro-Sar$\mathrm{MeVal}-\mathrm{OH})+\mathrm{H}]^{+}$and $[(\mathrm{H}-\mathrm{MeVal}-\mathrm{Sar}-\mathrm{OH})+\mathrm{H}]{ }^{+}$, respectively. The product ions of $\mathrm{m} / z 1053$ was attributed to neutral loss of Val-Pro-Sar-MeVal chain (398 Daltons - Da). The product ions of $\mathrm{m} / z 657$ and 558 confirmed the occurrence of another Pro-Sar$\mathrm{MeVal}$ amino acid residue. The product ion of $\mathrm{m} / z 459$ was attributed to the neutral loss Val-Pro-Sar-MeVal chain (398 Da) from the ion of $\mathrm{m} / \mathrm{z} 857$. This way, the main peak observed for LC-MS was attributed to actinomycin.

\section{Animal donors and in vitro fermentation assays}

Three multiparous Holstein cows in mid-lactation $(150 \pm 50$ DIM), with $542 \pm 32.25 \mathrm{~kg}$ of body weight and fitted with rumen cannula were used as inoculum donors. The cows were housed in individual pens with feed intake control and were submitted to twice-daily milking. Diets were offered to the cows in two meals (morning and afternoon) and were formulated for the nutritional requirements of lactating cows with $600 \mathrm{~kg}$ of body weight, and daily production of $32.0 \mathrm{~kg}$ of milk with $3.5 \%$ of fat, according to NRC recommendations (NRC, 2001). Diets consisted of corn silage as roughage (60\%), soybean meal $(15.5 \%)$, urea $(0.25 \%)$, ground corn $(23 \%)$ and mineral supplement (1.34\%), without any addition of ionophore and the roughage: concentrate ratio was 60:40.

In the inoculum composition, the solid and the liquid phase were collected from five points of the rumen (cranial, caudal, ventral, right and left) of the rumen. The liquid phase was collected by vacuum pump and stored in thermic bottles and the solid phase was stored in oxygen-free plastic bags and immediately sent to the laboratory. Equal volumes of the two phases were used, which were mixed for 10 seconds in the blender that was previously washed with buffer solution and aspirated with $\mathrm{CO}_{2}$, to recover the cellulolytic microorganisms attached to the solid fraction. After mixing, the resulting material was 
filtered through two layers of cotton tissue (cheesecloth) as described by Bueno et al. (2005) and kept in a water bath at $39^{\circ} \mathrm{C}$ with $\mathrm{CO}_{2}$ saturation until inoculation. The inoculum was injected into the bottles (inoculation) with a graduated plastic syringe of 10 $\mathrm{mL}$, and the bottles were sealed with rubber covers, agitated and then incubated in a forced-air oven at $39^{\circ} \mathrm{C}$ (corresponding to zero fermentation time).
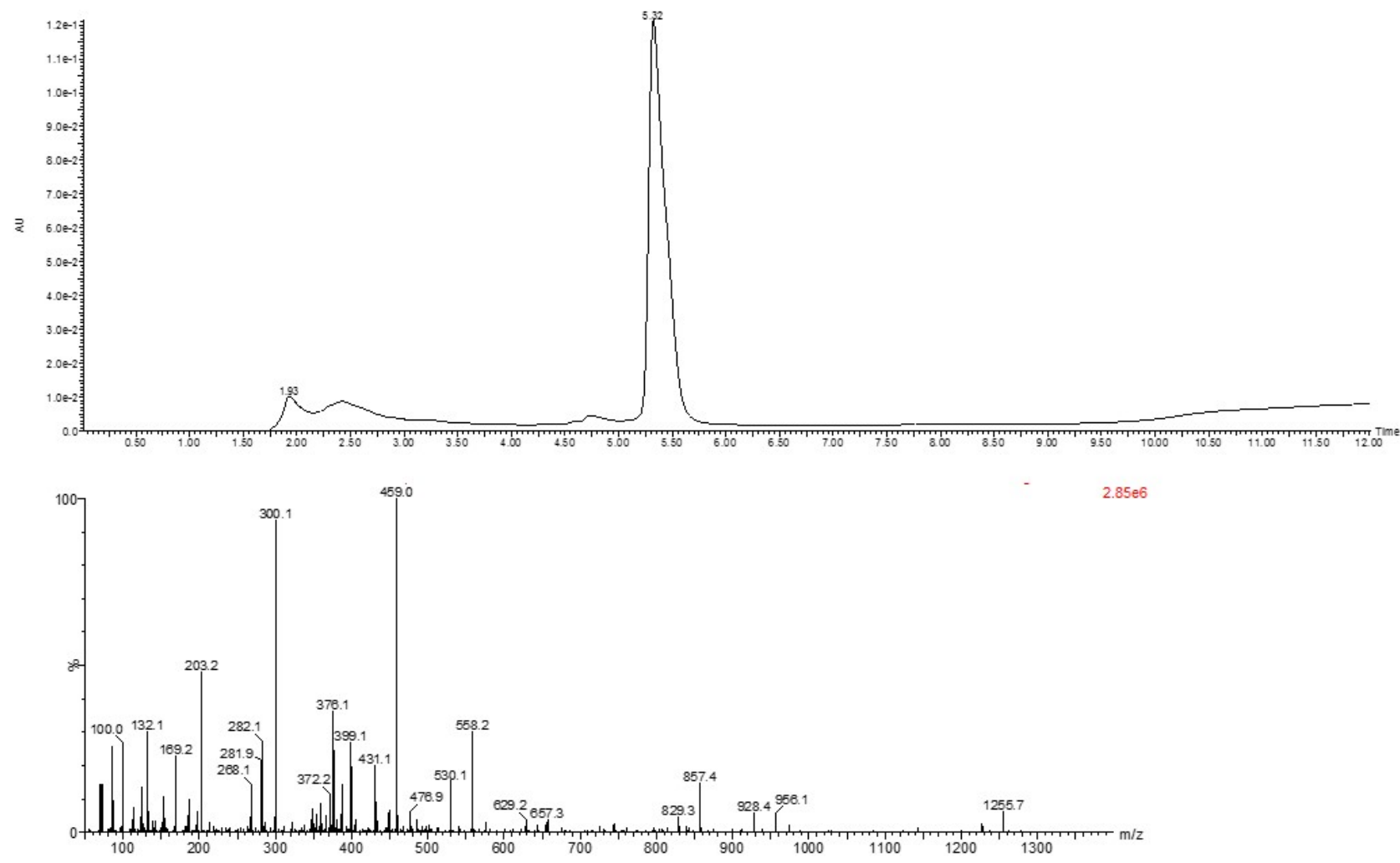

Figure 1 - CID spectra for LC-MS chromatogram to crude extracts from Caat and the ions to peak

The dietary chemical analysis was performed to determine the crude protein $(\mathrm{CP} ; \mathrm{N} \times 6.25$, method 990.03, AOAC, 2000); extract ether (EE; method 920.39; AOAC, 2000), neutral detergent fiber (NDF), using $\alpha$-amylase without sodium sulfite according to Mertens (2002), acid detergent fiber (ADF) and acid detergent lignin (ADL) according to Van Soest et al. (1991). The non-fibrous carbohydrates were calculated according to Weiss et al. (1992), described in the NRC (2001) (Table 1).

The in vitro fermentation assays were performed in fermenter bottles $(160 \mathrm{~mL})$ containing the substrate (consisting of the diet offered to the cows; with corn silage, soybean meal, urea, ground corn and mineral supplement, without any addition of ionophore), crude extracts and ruminal inoculum according to Theodorou et al. (1994) and as modified by Mauricio et al. (1999). Each bottle received $1 \mathrm{~g}$ of substrate ground to $1 \mathrm{~mm}$ of particle size, $90 \mathrm{~mL}$ of buffer solution, $10 \mathrm{~mL}$ of inoculum and the crude extracts (AMC and Caat) at four doses: 0.30, 0.60, 0.90 and 1.20 $\mathrm{mg} /$ bottle. Crude extracts were initially diluted in dimethyl sulfoxide (DMSO) at a concentration of 10 $\mathrm{mg}$ per $\mathrm{mL}\left(\mathrm{mg} . \mathrm{mL}^{-1}\right)$. The buffer solution used was prepared according to Lowe et al. (1985), which was composed of macromineral solutions, trace mineral elements, buffer and resazurin.

Twenty-four bottles were used for the in vitro fermentation assays ( 4 doses $\times 2$ crude extracts $\times$ triplicates) and 10 negative control bottles per each 
donor cow. In total, 102 bottles were considered [ $(4 \times$ $2 \times 3)+10$ ] $\times 3$. Negative control bottles did not receive the substrate; however, they were used for evaluation of gas production from the inoculum fermentation of diets directly offered to the donor cows.

Table 1 - Chemical composition of the substrate used on in vitro fermentation under lactating cows inoculum - Pirassununga - 2015

\begin{tabular}{cc}
\hline Chemical composition & $(\boldsymbol{g} / \mathbf{k g} \mathbf{D M})$ \\
\hline Crude Protein & 92.09 \\
Ether Extract & 30.87 \\
$\mathrm{NDF}^{1}$ & 288.29 \\
$\mathrm{ADF}^{2}$ & 169.01 \\
Lignin & 33.15
\end{tabular}

NDF - Neutral Detergent Fiber; ${ }^{2}$ ADF - Acid Detergent Fiber

\section{Cumulative gas production}

Readings of the accumulated gas pressure in each fermentation bottle were carried out using the "transducer" data logger DATTALOGGER (MAURICIO et al., 1999), at 4, 8, 12, 18, 24, 27, 30, 36 48,60 and $72 \mathrm{~h}$ after inoculation. After each reading, the remaining gas was released until the pressure read by the transducer reverted to zero, and the bottles were then quickly agitated and returned to the forced-air oven. This procedure was adopted to avoid excessive pressure inside the bottles, which can inhibit the fermentation by microorganisms when the pressure inside the bottle exceeds 7 psi (ABDALLA et al., 2012).

The gas volume was estimated according to Mauricio et al. (1999), and the following exponential model proposed by France et al. (1993) that was fitted to the gas production data to estimate lag time (LAG), potential gas production ( $\mathrm{A}$, the asymptotic gas production of the France model) and cumulative gas production at 24,48 and $72 \mathrm{~h}$ post-inoculation, according to the model: $\mathrm{Vt}=\mathrm{A}\{1-\exp [-\mathrm{b}(\mathrm{t}-\mathrm{L})-\mathrm{c}$ $\mathrm{x}(\sqrt{ } \mathrm{t}-\sqrt{\mathrm{L}})]\}$ where: $\mathrm{Vt}$ is the final volume of gas accumulated at time $t(\mathrm{~mL}), \mathrm{A}$ is the asymptotic gas production $(\mathrm{mL}), \mathrm{L}$ is the lag time and $\mathrm{b}(\mathrm{h}-1)$ and $\mathrm{c}(\mathrm{h}-$ $1 / 2)$ are constant fractional rates.
At the end of $72 \mathrm{~h}$, the bottles were placed in ice basins so that the fermentation process stopped and then two aliquots of fermentation fluid from each bottle were collected and stored at $-20^{\circ} \mathrm{C}$ for subsequent analysis of SCFA.

\section{SCFA concentrations}

The SCFA concentrations in the rumen fluid were measured by gas chromatography (GC-2014, Shimadzu, Japan) using a glass column (Stabilwax Restek, Bellefonte, PA, USA; $30 \mathrm{~m}$ of length/ $0.53 \mathrm{~mm}$ of internal diameter) at $145^{\circ} \mathrm{C}$ and a splitless injector and dual FID detector at $250^{\circ} \mathrm{C}$ using the method described by Erwin et al. (1961), and adapted by Getachew et al. (2004). Briefly, samples were centrifuged at $14,500 \times \mathrm{g}$ for $10 \mathrm{~min}$ and the supernatant $(800 \mu \mathrm{L})$ was transferred to a clean and dry flask with $200 \mu \mathrm{L}$ of $98-100 \%$ formic acid and $100 \mu \mathrm{L}$ of internal standard (2-ethyl-butyric acid $100 \mu \mathrm{M}$, Chem Service, USA). The external standard was prepared with acetic, propionic, isobutyric, butyric, valeric and isovaleric acids (Chem Service, USA) and the GC Solution ${ }^{\circledR}$ software (Shimadzu, Kyoto, Japan) was used to calculate the SCFA concentrations.

\section{Digestibility analysis}

The in vitro dry matter digestibility (IVDMD) and the in vitro organic matter digestibility (IVOMD) coefficients were determined according to Menke et al. (1979). The residues were filtered after $72 \mathrm{~h}$ of fermentation and then dried at $105^{\circ} \mathrm{C}$ for $24 \mathrm{~h}$ and weighed for IVDMD coefficients based on the weight difference. The IVOMD was estimated by the difference of ash residue remaining after ignition in a muffle furnace $\left(600^{\circ} \mathrm{C}\right)$.

\section{Statistical analysis}

The data were analyzed as a randomized block design using the Statistical Analysis System ${ }^{\circledR}$ computer program (SAS, 2001). Initially, we checked the residual normality and the homogeneity of variances by PROC UNIVARIATE. Response variables of in vitro ruminal 
fermentation were evaluated by the MIXED procedure and treatments were distributed in a $4 \times 2$ factorial arrangement (two crude extracts and four doses), totaling eight treatments and the control. The main effects of the extracts, doses and their interactions on response variables (SCFA, IVDMD and IVOMD) were analyzed according to the following model: $Y_{i j}=\mu+E_{i}$ $+D_{j}+E_{i} \times D_{j}+B_{k}+e_{i j k}$, where $Y i j=$ dependent variable; $\mu=$ the overall mean; $E_{i}=$ the fixed effect of extract $i ; D_{j}$ $=$ the fixed effect of dose $j ; E_{i} \times D_{j}=$ the fixed effect of the interaction between the extract and dose; $B_{k}=$ the random animal effect (block) and $\mathrm{e}_{\mathrm{ij}}=$ random error associated with each observation.

The cumulative gas productions at 24,48 and $72 \mathrm{~h}$ were analyzed as repeated measures and the error structure was chosen according to the Bayesian information criteria (BIC) for the evaluation of each variable, depending on the model: $Y_{i j k}=\mu+E_{i}+D_{j}+E_{i}$ $\times D_{j}+T_{k}+T_{k} \times E_{i}+T_{k} \times D_{j}+T_{k} \times D_{j} \times E_{i}+B_{k}+e_{i j k}$, where Yijk = variable dependent; $\mu=$ the overall mean; $E_{i}=$ the fixed effect of extract $i ; D_{j}=$ the fixed effect of dose $j ; E_{i} \times D_{j}=$ the fixed effect of the interaction between the extract and dose; $T_{k}=$ the fixed effect of time $k ; T_{k} \times E_{i}=$ the fixed effect of the interaction between time and extract; $T_{k} \times D_{j}=$ the fixed effect of the interaction between time and dose; $T_{k} \times D_{j} \times E_{i}=$ the fixed effect of the three-way interaction among time, dose, and extract, $B_{k}=$ the random animal effect (block) and $\mathrm{e}_{\mathrm{ijk}}=$ random error associated with each observation. The adjusted means were calculated and compared by the DIFF option 'statement' LSMEANS. The dose effect of each extract was decomposed in three orthogonal polynomial contrasts (linear, quadratic and cubic). The intercept and slope coefficients were obtained using the "estimate" option of MIXED procedure. For all the statistical analyses, significance was declared at $\mathrm{P} \leqslant 0.05$.

\section{Results}

There was no observed cubic effect in any of the analyzed variables and, therefore, the $P$ values will not be presented.

\section{Gas production}

There was no interaction among crude extract, doses, and time of incubation (Figure 2). However, we observed that the inclusion of Caat extract reduced the cumulative gas production at 24,48 and $72 \mathrm{~h}$ of incubation and the general mean of potential gas production (A) compared with AMC inclusion. Additionally, a linear effect of Caat dose was observed on the reduction of cumulative gas production (Table 2).

Different effects of AMC and Caat extracts on ruminal fermentation parameters were observed according to the time of fermentation. According to the regression analysis, the parameter $\mathrm{A}$ reduced linearly with the inclusion of Caat $[\mathrm{Y}=251.22$ ( $\mathrm{SE}=$ 16.277) $-0.238(\mathrm{SE}=0.081) \times$ Caat $(\mathrm{mg})](P=0.040)$. For each unit of Caat extract included, there was a decrease of the cumulative gas production by 1.6 times at $24 \mathrm{~h}(P=0.0296), 0.36$ times at $48 \mathrm{~h}(P=0.0003)$ and 0.30 times at $72 \mathrm{~h}(P=0.008)$. Similarly, with the inclusion of AMC extract, the cumulative gas production at $24 \mathrm{~h}$ of fermentation reduced linearly by $0.47 \mathrm{~mL} / \mathrm{g}$ for each $\mathrm{mg}$ of AMC [Y $=182.74(\mathrm{SE}=$ $11.496)-0.472(\mathrm{SE}=0.158) \times \mathrm{AMC}(\mathrm{mg})](P=0.010)$ (Table 2).

\section{Dry matter and organic matter in vitro digestibility}

There was no interaction effect between crude extract and dose on the IVDMD coefficient. However, an effect of Caat inclusion $(P=0.005)$ was observed on the IVOMD (Table 3 ). After $72 \mathrm{~h}$ of incubation, for each $\mathrm{mg}$ of Caat extract added, the IVOMD reduced linearly by 0.00011 percentage units $[\mathrm{Y}=0.747(\mathrm{SE}=$ $0.0103)-0.0001(\mathrm{SE}=0.0001) \times$ Caat $(\mathrm{mg})](P=0.028)$. On the other hand, no effect of AMC extract or dose was observed on the IVDMD and IVOMD coefficients.

\section{SCFA concentrations}

The inclusion of Caat increased the propionic acid concentration by $28 \%$ (when expressed in $\mathrm{mM}$ ) and by 
27\% (when expressed as \% of total fatty acids production $)(P=<.0001)$ at the higher dose when it was compared with the inclusion of AMC. Consequently, the acetate:propionate ratio was reduced by $22 \%$ with Caat compared to AMC ( $P=$ 0.0001). Moreover, compared with AMC, Caat doses linearly decreased the concentrations $(\mathrm{mM})$ of butyric acid in 59\% $(P=0.0021)$ and main effect of Caat inclusion was observed on the reduced of isovaleric concentration $(\mathrm{mM})(P=0.0078)$ (Table 4$)$. For each $\mathrm{mg}$ of Caat extract, there was a reduction of $0.03 \mathrm{mM}$ and $0.04 \%$ units of butyric acid concentration [ $\mathrm{Y}=$ $12.3992(\mathrm{SE}=2.7313)-0.0385(\mathrm{SE}=0.0073) \times$ Caat $(\mathrm{mg}) ; \mathrm{Y}=15.3844-0.0411 \times$ Caat $(\mathrm{mg})]$. Additionally, the concentration of isovaleric acid (\% of total SCFA) was also linearly reduced $(P=0.0374)$ by Caat.

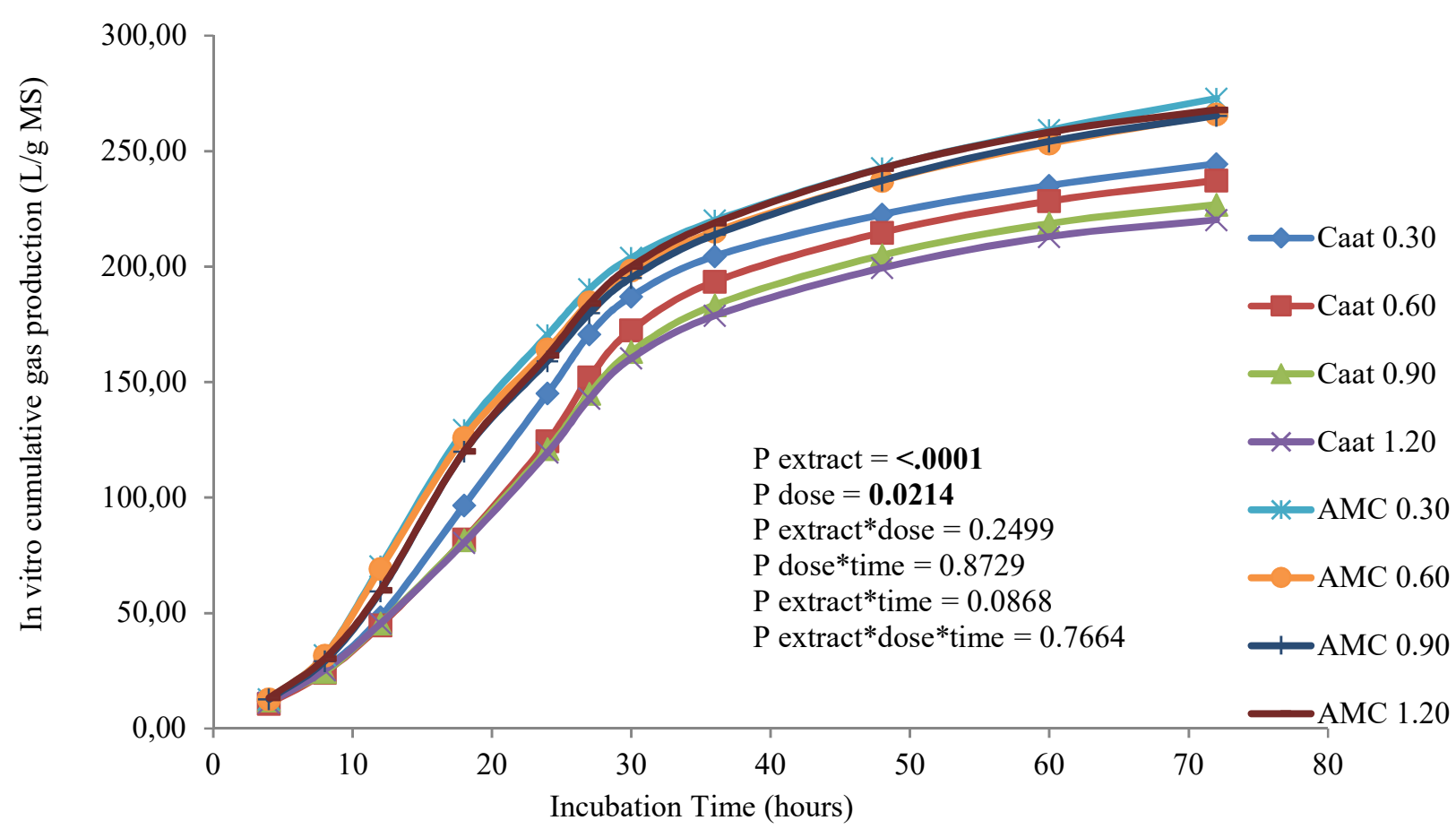

Figure 2 - In vitro total gas production of two crude extracts (Caat and AMC) derived from actinobacteria in four doses (0.3, 0.60, 0.90 and $1.20 \mathrm{mg}$ ) on in vitro rumen fermentation

\section{Discussion}

In this study, the crude extract Caat produced by actinobacteria isolated from soil of the Caatinga region of Brazil reduced the total gas production and resulted in an increase of propionic acid concentration in comparison to AMC inclusion. However, the doses included of Caat extract linearly reduced the organic matter digestibility. Thus, the results of this study indicate that the crude extract Caat has the potential to increase ruminal fermentation efficiency, and could be potentially used as an additive in ruminant diets. However, in vivo studies are needed to evaluate ruminal fermentation, as well as its relative efficiency against other additives for ruminal modulation (e.g., enzymes, essential oils, tannins, etc.).

There was a main effect of Caat extract inclusion (the mean value was higher for Caat) but there was no linearity effect for Caat dose on the propionic acid concentration, which is the main gluconeogenic pathway precursor used for glucose synthesis of ruminants (AMARAL et al., 1990). Duffield et al. (2008), in a meta-analysis on the effects of administrating monensin to ruminants, observed similar effects of monensin on propionic acid concentrations, as the supplemented animals showed a higher hepatic glucose production (gluconeogenesis). 
Table 2 - Cumulative gas production (mL/g), production potential gas (asymptotic A. mL/g of DM) and lag time (L) according to crude extracts (Caat and AMC) in different doses derived from actinobacteria on in vitro rumen fermentation - Pirassununga - 2015

\begin{tabular}{|c|c|c|c|c|c|c|c|c|c|c|c|c|c|c|c|c|c|c|}
\hline & \multicolumn{10}{|c|}{ Crude Extracts } & \multirow{3}{*}{ SEM } & \multicolumn{7}{|c|}{$P$-Value } \\
\hline & \multirow[b]{2}{*}{0.30} & \multicolumn{4}{|c|}{ Caat (mg) } & \multicolumn{5}{|c|}{ AMC (mg) } & & \multirow{2}{*}{ Extract } & \multirow{2}{*}{ Dose } & \multirow{2}{*}{ Ext $^{\star}$ Dose } & \multicolumn{2}{|c|}{ Caat } & \multicolumn{2}{|c|}{ AMC } \\
\hline & & 0.60 & 0.90 & 1.20 & Mean & 0.30 & 0.60 & 0.90 & 1.20 & Mean & & & & & $\mathbf{L}$ & $\mathbf{Q}$ & $\mathbf{L}$ & $\mathbf{Q}$ \\
\hline $\mathbf{A}(\mathrm{mL} / \mathrm{g})$ & 242.9 & 239.1 & 228.7 & 222.5 & $233.3^{b}$ & 264.0 & 260.2 & 261.7 & 268.6 & $263.6^{a}$ & 6.12 & $<.0001$ & 0.56 & 0.22 & $0.04^{1}$ & 0.85 & 0.62 & 0.44 \\
\hline $\mathbf{L}$ (hours) & 5.56 & 6.11 & 7.08 & 5.51 & 6.06 & 9.65 & 2.74 & 3.57 & 3.59 & 4.89 & 1.05 & 0.62 & 0.71 & 0.60 & 0.73 & 0.07 & 0.39 & 0.66 \\
\hline Hours & \multicolumn{10}{|c|}{ Cumulative Gas Production (mL/g) } & & & & & & & & \\
\hline 24 & 145.1 & 124.4 & 121.0 & 119.6 & $127.5^{\mathrm{b}}$ & 170.4 & 164.2 & 159.1 & 161.7 & $163.9^{\mathrm{a}}$ & 6.43 & $<.0001$ & 0.09 & 0.66 & $0.02^{2}$ & 0.16 & $0.010^{3}$ & 0.06 \\
\hline 48 & 222.6 & 214.8 & 204.9 & 199.4 & $210.4^{\mathrm{b}}$ & 242.7 & 237.2 & 237.3 & 242.6 & $239.9^{\mathrm{a}}$ & 5.86 & $<.0001$ & 0.07 & 0.09 & $0.0003^{4}$ & 0.65 & 0.99 & 0.42 \\
\hline 72 & 244.5 & 237.3 & 226.8 & 220.2 & $232.2^{\mathrm{b}}$ & 272.8 & 265.9 & 265.4 & 267.9 & $268.0^{\mathrm{a}}$ & 6.27 & $<.0001$ & 0.09 & 0.30 & $0.008^{5}$ & 0.94 & 0.66 & 0.52 \\
\hline
\end{tabular}

Table 3 - Effect of two crude extracts (Caat and AMC) produced by actinobacteria in four doses (0.30. 0.60. 0.90 and 1.20 mg) on IVDMD and IVOMD on in vitro rumen fermentation - Pirassununga - 2015

\begin{tabular}{|c|c|c|c|c|c|c|c|c|c|c|c|c|c|c|c|c|c|}
\hline \multirow{3}{*}{ Variables } & \multicolumn{8}{|c|}{ Crude Extracts } & \multirow{3}{*}{ Mean } & \multirow{3}{*}{ SEM } & \multicolumn{7}{|c|}{$P$-Value } \\
\hline & \multicolumn{4}{|c|}{ Caat (mg) } & \multicolumn{4}{|c|}{ AMC (mg) } & & & \multirow{2}{*}{ Extract } & \multirow{2}{*}{ Dose } & \multirow{2}{*}{ Ext $^{\star}$ Dose } & \multicolumn{2}{|c|}{ Caat } & \multicolumn{2}{|c|}{ AMC } \\
\hline & 0.30 & 0.60 & 0.90 & 0.120 & 0.30 & 0.60 & 0.90 & 0.120 & & & & & & $\mathbf{L}$ & $\mathbf{Q}$ & $\mathbf{L}$ & $\mathbf{Q}$ \\
\hline IVDMD (\%) & 73.78 & 73.72 & 74.45 & 73.66 & 72.83 & 74.15 & 73.99 & 73.56 & 73.76 & 0.002 & 0.48 & 0.37 & 0.64 & 0.41 & 0.52 & 0.66 & 0.50 \\
\hline IVOMD (\%) & 78.61 & 78.47 & 76.98 & 75.99 & 77.34 & 78.32 & 76.01 & 75.95 & 77.16 & 0.004 & 0.25 & 0.0051 & 0.80 & $0.02^{\star}$ & 0.72 & 0.50 & 0.80 \\
\hline
\end{tabular}

${ }^{1}$ IVDMD - In vitro dry matter digestibility; ${ }^{2} \mathrm{IVOMD}-$ In vitro organic matter digestibility; ${ }^{3} \mathrm{SEM}-$ standard error $\mathrm{mean} ;{ }^{\star} \mathrm{Y}=0.747(\mathrm{SE}=0.0103)$ $0.00011(\mathrm{SE}=0.000103) \times$ Caat $(\mathrm{mg})$ 
Table 4 - Effect of two crude extracts (Caat and AMC) derived from actinobacteria added in four doses (0.30. 0.60. 0.90 and $1.20 \mathrm{mg})$ per bottle on shortchain fatty acids (SCFA) concentration (mM and \%) on in vitro rumen fermentation - Pirassununga - 2015

\begin{tabular}{|c|c|c|c|c|c|c|c|c|c|c|c|c|c|c|c|c|c|c|}
\hline \multirow{3}{*}{ SCFA } & \multicolumn{9}{|c|}{ Crude Extracts } & \multirow{3}{*}{ Mean } & \multirow{3}{*}{ SEM } & \multicolumn{7}{|c|}{$P$-Value } \\
\hline & \multicolumn{4}{|c|}{ Caat (mg) } & \multirow{2}{*}{ Mean } & \multicolumn{4}{|c|}{ AMC (mg) } & & & \multirow{2}{*}{ Extract } & \multirow{2}{*}{ Dose } & \multirow{2}{*}{ Ext ${ }^{*}$ Dose } & \multicolumn{2}{|c|}{ Caat } & \multicolumn{2}{|c|}{ AMC } \\
\hline & 0.30 & 0.60 & 0.90 & 1.20 & & 0.30 & 0.60 & 0.90 & 1.20 & & & & & & $\mathbf{L}$ & Q & $\mathbf{L}$ & $\mathbf{Q}$ \\
\hline \multicolumn{19}{|c|}{$m M$} \\
\hline Acetic & 35.18 & 33.91 & 34.57 & 34.21 & 34.47 & 34.02 & 35.40 & 32.65 & 35.02 & 34.27 & 0.67 & 0.85 & 0.872 & 0.63 & 0.80 & 0.78 & 0.85 & 0.70 \\
\hline Propionic & 28.25 & 27.34 & 28.16 & 28.93 & $28.17^{\mathrm{a}}$ & 22.33 & 23.16 & 20.81 & 21.29 & $21.90^{\mathrm{b}}$ & 0.96 & $<.0001$ & 0.950 & 0.68 & 0.56 & 0.48 & 0.47 & 0.92 \\
\hline Iso Butiric & 0.90 & 0.75 & 0.67 & 0.62 & 0.74 & 0.96 & 0.79 & 0.73 & 0.89 & 0.85 & 0.07 & 0.071 & 0.0530 & 0.40 & $0.005^{1}$ & 0.38 & 0.55 & 0.15 \\
\hline Butiric & 11.60 & 9.71 & 8.62 & 8.10 & $9.51^{\mathrm{b}}$ & 15.61 & 15.06 & 14.83 & 15.32 & $15.20^{\mathrm{a}}$ & 1.03 & $<.0001$ & 0.0542 & 0.17 & $0.002^{2}$ & 0.21 & 0.74 & 0.50 \\
\hline IsoValeric & 1.25 & 1.11 & 1.09 & 1.04 & $1.12^{\mathrm{b}}$ & 1.23 & 1.27 & 1.21 & 1.30 & $1.25^{\mathrm{a}}$ & 0.10 & 0.007 & 0.485 & 0.16 & 0.08 & 0.55 & 0.64 & 0.67 \\
\hline Valeric & 1.47 & 1.41 & 1.33 & 1.29 & 1.38 & 1.44 & 1.52 & 1.47 & 1.52 & 1.49 & 0.07 & 0.30 & 0.953 & 0.83 & 0.22 & 0.92 & 0.61 & 0.80 \\
\hline A/P Ratio & 1.29 & 1.26 & 1.23 & 1.20 & $1.24^{\mathrm{b}}$ & 1.60 & 1.61 & 1.59 & 1.65 & $1.61^{\mathrm{a}}$ & 0.07 & 0.0001 & 0.991 & 0.92 & 0.29 & 0.98 & 0.74 & 0.78 \\
\hline Total of SCFA & 78.66 & 74.23 & 74.45 & 74.19 & 75.38 & 75.58 & 77.2 & 71.69 & 75.33 & 74.95 & 3.47 & 0.56 & 0.83 & 0.66 & 0.38 & 0.50 & 0.57 & 0.76 \\
\hline \multicolumn{19}{|c|}{$\%$} \\
\hline Acetic & 44.66 & 45.69 & 46.41 & 46.24 & 45.75 & 44.95 & 45.81 & 45.52 & 46.54 & 45.71 & 0.40 & 0.96 & 0.65 & 0.95 & 0.13 & 0.42 & 0.11 & 0.88 \\
\hline Propionic & 36.51 & 37.11 & 38.32 & 39.02 & $37.74^{\mathrm{a}}$ & 29.80 & 30.18 & 29.41 & 28.58 & $29.49^{\mathrm{b}}$ & 1.50 & $<.0001$ & 0.94 & 0.46 & 0.08 & 0.96 & 0.51 & 0.69 \\
\hline Iso Butiric & 1.12 & 1.00 & 0.87 & 0.83 & $0.96^{\mathrm{b}}$ & 1.27 & 1.02 & 0.98 & 1.17 & $1.11^{\mathrm{a}}$ & 0.08 & 0.04 & 0.08 & 0.46 & $0.001^{3}$ & 0.39 & 0.58 & 0.16 \\
\hline Butiric & 14.35 & 12.84 & 11.24 & 10.77 & $12.30^{\mathrm{b}}$ & 20.47 & 19.38 & 20.41 & 20.02 & $20.07^{\mathrm{a}}$ & 1.23 & $<.0001$ & 0.10 & 0.11 & $<.0001^{4}$ & 0.07 & 0.97 & 0.72 \\
\hline IsoValeric & 1.54 & 1.47 & 1.41 & 1.39 & $1.45^{\mathrm{b}}$ & 1.61 & 1.63 & 1.64 & 1.67 & $1.64^{\mathrm{a}}$ & 0.11 & $<.0001$ & 0.72 & 0.12 & $0.03^{5}$ & 0.59 & 0.20 & 0.99 \\
\hline Valeric & 1.83 & 1.88 & 1.74 & 1.74 & 1.80 & 1.89 & 1.97 & 2.04 & 2.02 & 1.98 & 0.08 & 0.19 & 0.99 & 0.88 & 0.38 & 0.82 & 0.31 & 0.59 \\
\hline
\end{tabular}


Additionally, Caat inclusion reduced the concentration of isobutyric, butyric and isovaleric acids, suggesting that the actinomycin metabolite may have an inhibition effect on Gram-positive bacteria (the main producers of these fatty acids) instead of a stimulation effect on Gram-negative (propionic acidproducers); similar to the monensin mode of action (RUSSELL, 1987).

This study also showed that the Caat extract reduced the acetate:propionate ratio (A:P). This ratio was $30 \%$ lower $(1.24 \mathrm{mM})$ compared to those observed in the inclusion of AMC extract effect $(1.61 \mathrm{mM})$. Using an in vitro assay at $24 \mathrm{~h}$, Castro-Montoya et al. (2012) observed that incubations of 5 to $8 \mu \mathrm{M}$ of monensin in a substrate with $70 \%$ forage reduced the $\mathrm{A}: \mathrm{P}$ ratio. This decrease of A:P ratio was also observed in an in vivo study that administered $33 \mathrm{mg} / \mathrm{kg}$ of monensin to Holstein steers (KHORRAMI et al., 2015). However, in another in vivo study, monensin was given to 4 lactating cows at a dose of $350 \mathrm{mg} / \mathrm{kg}$ and the ratio A:P was not affected (BENCHAAR et al., 2006).

This difference observed in the effects of the A:P ratio in vivo may have occurred because monensin can interact with diets and the metabolic status of the animals studied (BENCHAAR et al., 2006). The monensin dose used directly affects the effects on the A: $P$ ratio and this change is much greater when a high dose is included. In addition, it has been reported that the decrease of the A:P ratio is favored by the type of diet used, with greater reduction by a diet with more easily fermentable carbohydrates (JENKINS et al., 2003). In addition, the efficacy of monensin use in SCFA profiles has been reported related to the concentrate proportion in the total mixed diet, or in the substrate used, whereas diets with lower inclusion of forage (50:50) have greater effect of the A:P ratio decrease than in diets with high forage inclusion (70:30) (RAMANZIN et al., 1997).

Schelling (1984) reported changes in in vivo ruminal fermentation after supplementation with monensin on SCFA production, intake and gas production. The cumulative gas production results of the present study showed that the parameter $\mathrm{A}$, as well as the values at 24,48 and $72 \mathrm{~h}$, decreased linearly according to the increase of Caat extract dose. Thus, the lower gas production observed with the greatest addition of Caat $(120 \mathrm{mg}$ ) could be explained by the ruminal bacteria selection effect, which resulted in lower $\mathrm{CO}_{2}$ production (NAGARAJA et al., 1997). Similar to the results of this study, Faria et al. (2008) observed a reduction of total gas production from 12 to $96 \mathrm{~h}$ on an in vitro rumen fermentation assay with the addition of propylene and monensin.

In terms of the IVDMD and IVOMD coefficients, the increase of Caat dose reduced the IVOMD; however, no main effect was observed for the extracts. With a similar result, Weimer et al. (2011) mixed ruminal microbes incubated for $24 \mathrm{~h}$ in vitro under different starch levels and showed that the in vitro fiber digestibility was the same for monensin-adapted inoculum incubated with monensin and inoculate from the same cows prior to adaptation and incubated in the absence of monensin. Different from what we observed in the present study, Lemenager et al. (1978) observed a reduction in the dry matter digestibility in cows that were not adapted to diets with the inclusion of monensin. The increase of the dose observed in the present study probably resulted in the inhibition of cellulolytic bacteria, similar to monensin effects on feed digestion (NARVAEZ et al., 2013). In addition, the in vitro gas production systems may allow an excessive accumulation of some end fermentation products, which could inhibit microbial activity and, consequently, reduce IVDMD (NISA et al., 1999).

The present study evaluated the inclusion of crude extracts produced by actinobacteria, which could have more than one active metabolite. Based on the results of Crevelin et al. (2013), AMC extract was composed of a class of macrolides known as bafilomycins with different structures besides other compounds. One possible limitation of the present study was that crude extracts, which are a mixture of active compounds, were used instead of the isolated active metabolites. 
For both extracts, the active metabolite in the mixture may correspond to a lower concentration within the mixture compared to the concentration of the same compound if it were pure. Thus, the observed effect of the inclusion of this mixture may not have been so pronounced by the fact that in this mixture may have compounds of different structures from ionophores, which may not contribute to the expected effect.

Even at low doses compared to the dose of pure ionophores normally used in in vitro assays, the crude extract Caat caused similar effects on reduction of gas production and modulation of SCFA concentration, which could indicate, in this case, that it could be used at high doses of the study and thus with a more pronounced effect since the AMC presented inconsistent results. In addition, the comparisons in this study were made between the dose effects of each extract for each variable, and each dose was corrected with an internal control.

\section{References}

ABDALLA, A. L.; LOUVANDINI, H.; SALLAM, S. M. A. H.; BUENO, I. C. S.; TSAI, S. M.; FIGUEIRA, A. V. O. In vitro evaluation, in vivo quantification, and microbial diversity studies of nutritional strategies for reducing enteric methane production. Tropical Animal Health and Production, v. 44, n. 5, p. 953-964, 2012. doi: 10.1007/s11250-011-9992-0.

AMARAL, D. M.; VEENHUIZEN, J. J.; DRACKLEY, J. K.; COOLEY, M. H.; MCGILlIARD, A. D.; YOUNG, J. W. Metabolism of propionate, glucose, and carbon dioxide as affected by exogenous glucose in dairy cows at energy equilibrium. Journal of Dairy Science, v. 73, n. 5, p. 12441254, 1990. doi: 10.3168/jds.S0022-0302(90)78789-9.

ASSOCIATION OF OFFICIAL AGRICULTURAL CHEMISTS (AOAC). Official methods of analysis. 17th ed. Gaithersburg, MD: AOAC International, 2000.

BENCHAAR, C.; PETIT, H. V; BERTHIAUME, R.; WHYTE, T. D.; CHOUINARD, P. Y. Effects of addition of essential oils and monensin premix on digestion, ruminal fermentation, milk production, and milk composition in dairy cows. Journal of Dairy Science, v. 89, n. 11, p. 4352 4364, 2006. doi: 10.3168/jds.S0022-0302(06)72482-1.

\section{Conclusion}

The highest dose of Caat crude extract ( $120 \mathrm{mg}$ ) has potential as an additive in ruminant diets to increase ruminal fermentation efficiency. The inclusion of this extract increased the concentration of propionic acid and reduced the A:P ratio and the cumulative gas production at 24,48 and $72 \mathrm{~h}$, although the dose increase linearly reduced the in vitro organic matter digestibility on the in vitro rumen fermentation assay. The use of AMC only reduced the cumulative gas production after $24 \mathrm{~h}$ of incubation.

\section{Conflict of Interest}

The author(s) declare(s) that there is no conflict of interest regarding the publication of this article.

\section{Acknowledgments}

This research received a special scholarship from Fundação de Amparo à Pesquisa do Estado de São Paulo (FAPESP) - Process 2014/08905-5) and financial support (grants no. 2013/20094-0 and 2015 /50729-7).

BUENO, I. C. S.; CABRAL FILHO, S. L. S.; GOBBO, S. P.; LOUVANDINI, H.; VITTI, D. M. S. S.; ABDALLA, A. L. Influence of inoculum source in a gas production method. Animal Feed Science and Technology, v. 123-124, p. 95105, 2005. doi: 10.1016/j.anifeedsci.2005.05.003.

CALSAMIGLIA, S.; BUSQUET, M.; CARDOZO, P. W.; CASTILLEJOS, L.; FERRET, A. Invited Review: essential oils as modifiers of rumen microbial fermentation. Journal of Dairy Science, v. 90, n. 6, p. 2580-2595, 2007. doi: 10.3168/jds.2006-644.

CASTRO-MONTOYA, J. M.; MAKKAR, H. P. S.; BECKER, $K$. Effects of monensin on the chemical composition of the liquid associated microbial fraction in an in vitro rumen fermentation system. Livestock Science, v. 150, n. 1-3, p. 414-418, 2012. doi: 10.1016/j.livsci.2012.09.026.

CREVELIN, E. J.; CANOVA, S. P.; MELO, I. S.; ZUCCHI, T. D.; SILVA, R. E.; MORAES, L. A. B. Isolation and characterization of phytotoxic compounds produced by Streptomyces sp. amc 23 from red mangrove (Rhizophora mangle). Applied Biochemistry and Biotechnology, v. 171, n. 7, p. 1602-1616, 2013. doi: 10.1007/s12010-013-0418-5. 
CREVEliN, E. J.; CROTTI, A. E. M.; ZUCCHI, T. D.; MELO, I. S.; MORAES, L. A. B. Dereplication of Streptomyces sp. AMC 23 polyether ionophore antibiotics by accurate-mass electrospray tandem mass spectrometry. Journal of Mass Spectrometry, v. 49, n. 11, p. 1117-1126, 2014. doi: 10.1002/jms.3432.

DINIUS, D. A.; SIMPSON, M. E.; MARSH, P. B. Effect of monensin fed with forage on digestion and the ruminal ecosystem of steers. Journal of Animal Science, v. 42, n. 1, p. 229-234, 1976.

DOMESCIK, E. J.; MARTIN, S. A. Effects of laidlomycin propionate and monensin on the in vitro mixed ruminal microorganism fermentation. Journal of Animal Science, v. 77 , n. 8, p. 2305-2312, 1999.

DUFFIELD, T. F.; RABIEE, A. R.; LEAN, I. J. A metaanalysis of the impact of monensin in lactating dairy cattle. Part 1. Metabolic effects. Journal of Dairy Science, v. 91, n. 4, p. 1334-1346, 2008. doi: 10.3168/jds.2007-0607.

ERWIN, E. S.; MARCO, G. J.; EMERY, E. M. Volatile fatty acid analyses of blood and rumen fluid by gas chromatography. Journal of Dairy Science, v. 44, n. 9, p. 1768-1771, 1961. doi: 10.3168/jds.S0022-0302(61)89956-6.

FARIA, B. N.; REIS, R. B.; MAURÍCIO, R. M.; LANA, A. M. Q.; SOARES, S. R. V.; SATURNINO, H. M.; COELHO, S. G. Efeitos da adição de propilenoglicol ou monensina à silagem de milho sobre a cinética de degradação dos carboidratos e produção cumulativa de gases in vitro. Arquivo Brasileiro de Medicina Veterinária e Zootecnia, v. 60, n. 4, p. 896-903, 2008. doi: 10.1590/S0102-09352008000400019.

FRANCE, J.; DHANOA, M. S.; THEODOROU, M. K.; LISTER, S. J.; DAVIES, D. R.; ISAC, D. A model to interpret gas accumulation profiles associated with in vitro degradation of ruminant feeds. Journal of Theoretical Biology, v. 163, n. 1, p. 99-111, 1993. doi: 10.1006/jtbi.1993.1109.

GETACHEW, G.; ROBINSON, P. H.; DEPETERS, E. J.; TAYLOR, S. J. Relationships between chemical composition, dry matter degradation and in vitro gas production of several ruminant feeds. Animal Feed Science and Technology, v. 111, n. 1-4, p. 57-71, 2004. doi: 10.1016/S0377-8401(03)00217-7.

JANI, P.; EMMERT, J.; WOHLGEMUTH, R. Process analysis of macrotetrolide biosynthesis during fermentation by means of direct infusion LC-MS. Biotechnology Journal, v. 3, n. 2, p. 202-208, 2008. doi: 10.1002/biot.200700174.

JENKINS, T. C.; FELLNER, V.; MCGUFFEY, R. K. Monensin by fat interactions on trans fatty acids in cultures of mixed ruminal microorganisms grown in continuous fermentors fed corn or barley. Journal of Dairy Science, v. 86, n. 1, p. 324-330, 2003. doi: 10.3168/jds.S0022-0302(03)73609-1.

KHORRAMI, B.; VAKILI, A. R.; MESGARAN, M. D.; KLEVENHUSEN, F. Thyme and cinnamon essential oils: potential alternatives for monensin as a rumen modifier in beef production systems. Animal Feed Science and Technology, v. 200, p. 8-16, 2015. doi: 10.1016/j.anifeedsci.2014.11.009.

LAZZARINI, A.; CAVALETTI, L.; TOPPO, G.; MARINELLI, F. Rare genera of actinomycetes as potential producers of new antibiotics. Antonie van Leeuwenhoek, v. 78, n. 3-4, p. 399-405, 2000. doi: 10.1023/A:1010287600557.

LEMENAGER, R. P.; OWENS, F. N.; SHOCKEY, B. J.; LUSBY, K. S.; TOTUSEK, R. Monensin effects on rumen turnover rate, twenty-four hour vfa pattern, nitrogen components and cellulose disappearance. Journal of Animal Science, v. 47, n. 1, p. 255-261, 1978. doi: 10.2527/jas1978.471255x.

LOWE, S. E.; THEODOROU, M. K.; TRINCI, A. P. J.; HESPELL, R. B. Growth of anaerobic rumen fungi on defined and semi-defined media lacking rumen fluid. Journal of General Microbiology, v. 131, p. 2225-2229, 1985.

MAURICIO, R. M.; MOULD, F. L.; DHANOA, M. S.; OWEN, E.; CHANNA, K. S.; THEODOROU, M. K. A semi-automated in vitro gas production technique for ruminant feedstuff evaluation. Animal Feed Science and Technology, v. 79, n. 4, p. 321-330, 1999. doi: 10.1016/S0377-8401(99)00033-4.

MCGUFFEY, R. K.; RICHARDSON, L. F.; WILKINSON, J. I. D. Ionophores for dairy cattle: current status and future outlook. Journal of Dairy Science, v. 84, p. E194-E203, 2001. Supplement. doi: 10.3168/jds.S0022-0302(01)70218-4.

MENKE, K. H.; RAAB, L.; SALEWSKI, A.; STEINGASS, H.; FRITZ, D.; SCHNEIDER, W. The estimation of the digestibility and metabolizable energy content of ruminant feedingstuffs from the gas production when they are incubated with rumen liquor in vitro. The Journal of Agricultural Science, v. 93, n. 1, p. 217-222, 1979. doi: $10.1017 /$ S0021859600086305.

MERTENS, D. R. Gravimetric determination of amylasetreated neutral detergent fiber in feeds with refluxing in beakers or crucibles: collaborative study. Journal of AOAC International, v. 85, n. 6, p. 1217-1240, 2002.

NAGARAJA, T. G.; NEWBOLD, C. J.; VAN NEVEL, C. J.; DEMEYER, D. I. Manipulation of ruminal fermentation. In: HOBSON, P. N.; STEWART, C. S. (Ed.). The rumen microbial ecosystem. Dordrecht: Springer Netherlands, 1997. p. 523-632.

NARVAEZ, N.; WANG, Y.; MCALLISTER, T. Effects of 
extracts of Humulus lupulus (hops) and Yucca schidigera applied alone or in combination with monensin on rumen fermentation and microbial populations in vitro. Journal of the Science of Food and Agriculture, v. 93, n. 10, p. $2517-$ 2522, 2013. doi: 10.1002/jsfa.6068.

NEWBOLD, C. J.; WALLACE, R. J.; WALKER, N. D. The effect of tetronasin and monensin on fermentation, microbial numbers and the development of ionophoreresistant bacteria in the rumen. The Journal of Applied Bacteriology, v. 75, n. 2, p. 129-134, 1993. doi: 10.1111/j.1365-2672.1993.tb02757.x.

NISA, M. U.; SARWAR, M.; BILAL, Q. Review: effect of ionophores on metabolic energetics in cattle. International Journal Agricultural Biological, v. 1, p. 66-69, 1999.

NATIONAL RESEARCH COUNCIL (NRC). Nutrient requirements of dairy cattle: Seventh Revised Edition. Washington, DC: The National Academies Press, 2001. doi: $10.17226 / 9825$.

RAMANZIN, M.; BAILONI, L.; SCHIAVON, S.; BITTANTE, G. Effect of monensin on milk production and efficiency of dairy cows fed two diets differing in forage to concentrate ratios 1. Journal of Dairy Science, v. 80, n. 6, p. 1136-1142, 1997. doi: 10.3168/jds.S0022-0302(97)76040-5.

RUSSELL, J. B. A proposed mechanism of monensin action in inhibiting ruminant bacterial growth: effects on ion flux and protonmotive force. Journal of Animal Science, v. 64, n. 5, p. 1519-1525, 1987.

RUSSELL, J. B.; STROBEL, H. J. Effect of ionophores on ruminal fermentation. Applied and Environmental Microbiology, v. 55, n. 1, p. 1-6, 1989.

SCHELLING, G. T. Monensin mode of action in the rumen.
Journal of Animal Science, v. 58, n. 6, p. 1518-1527, 1984.

STATISTICAL ANALYSIS SYSTEM (SAS). System for Microsoft Windows: release 8.2. Cary: SAS Institute, 2001. CD-ROM.

THEODOROU, M. K.; WILLIAMS, B. A.; DHANOA, M. S.; MCALLAN, A. B.; FRANCE, J. A simple gas production method using a pressure transducer to determine the fermentation kinetics of ruminant feeds. Animal Feed Science and Technology, v. 48, n. 3-4, p. 185-197, 1994. doi: 10.1016/0377-8401(94)90171-6.

VAN SOEST, P. J.; ROBERTSON, J. B.; LEWIS, B. A. Methods for dietary fiber, neutral detergent fiber, and nonstarch polysaccharides in relation to animal nutrition. Journal of Dairy Science, v. 74, n. 10, p. 3583-3597, 1991. doi: 10.3168/jds.S0022-0302(91)78551-2.

WEIMER, P. J.; STEVENSON, D. M.; MERTENS, D. R.; HALL, M. B. Fiber digestion, VFA production, and microbial population changes during in vitro ruminal fermentations of mixed rations by monensin-adapted and unadapted microbes. Animal Feed Science and Technology, v. 169, n. 1-2, p. 68-78, 2011. doi: 10.1016/j.anifeedsci.2011.06.002.

WEISS, W. P.; CONRAD, H. R.; ST. PIERRE, N. R. A theoretically-based model for predicting total digestible nutrient values of forages and concentrates. Animal Feed Science and Technology, v. 39, n. 1-2, p. 95-110, 1992. doi: 10.1016/0377-8401(92)90034-4.

WILLS, R. H.; O'CONNOR, P. B. Structural characterization of actinomycin $\mathrm{d}$ using multiple ion isolation and electron induced dissociation. Journal of The American Society for Mass Spectrometry, v. 25, n. 2, p. 186-195, 2014. doi: 10.1007/s13361-013-0774-y. 